\title{
ANALISIS FAKTOR YANG MEMPENGARUHI HUMAN \\ DEVELOPMENT INDEX (HDI) PADA 6 DAERAH TERTINGGAL DI PULAU JAWATAHUN 2010-2016
}

\author{
Yunita Firdha Kyswantoro \\ PPIE Fakultas Ekonomi dan Bisnis Universitas Brawijaya \\ yunitafirdhak@gmail.com
}

\begin{abstract}
Disadvantaged areas are districts whose areas and communities are less developed when compared to other regions on a national scale. Java Island as the contribution of the highest economic growth in Indonesia in fact accounted for 6 of 122 disadvantaged areas in Indonesia, namely Kab. Bondowoso, Kab. Situbondo, Kab. Bangkalan, Kab.Sampang, Kab. Pandeglang, Kab. Lebak. One of the criteria of disadvantaged areas is human resources, this can be measured through HDI (Human Development Index). The number of poor people, labor force and GRDP per capita are some factors that are considered to illustrate the influence of HDI in 6 disadvantaged areas. This research used Random Effect Model (REM) panel data regression in 6 disadvantaged areas in Java Island 2010 - 2016. The result of this research, labor force variable has no significant effect to Human Development Index (HDI). While the number of poor and PDRB perkapita have a significant effect on HDI in 6 disadvantaged areas in Java. It is therefore an effective way to accelerate the growth of economic growth in underdeveloped areas related to HDI through the decline of the number of poor people with the creation of labor-intensive jobs which in turn will increase the per capita GDP. Thus, increasing GRDP per capita will increase Human Development Index (HDI) where HDI is one indicator in economic growth of a region.
\end{abstract}

Keywords: Disadvantaged Areas, Human Development Index, GRDP per capita, poverty, labor force

\begin{abstract}
ABSTRAK
Daerah tertinggal merupakan kabupaten yang wilayah serta masyarakatnya kurang berkembang jika dibandingkan dengan wilayah lain dalam skala nasional. Pulau Jawa sebagai kontribusi pertumbuhan ekonomi tertinggi di Indonesia nyatanya menyumbang 6 dari 122 daerah tertinggal di Indonesia, yaitu Kab. Bondowoso, Kab. Situbondo, Kab. Bangkalan, Kab.Sampang, Kab. Pandeglang, Kab. Lebak. Salah satu kriteria daerah tertinggal yaitu mengenai sumberdaya manusia, hal ini bisa diukur melalui HDI (Human Development Index). Jumlah penduduk miskin, angkatan kerja dan PDRB perkapita adalah beberapa faktor yang dianggap dapat menggambarkan pengaruh HDI pada 6 daerah tertinggal. Penelitian kali ini menggunakan regresi data panel model Random Effect (REM) pada 6 daerah tertinggal di Pulau Jawa tahun 2010- 2016. Hasil penelitian kali ini, variabel angkatan kerja tidak berpengaruh signifikan terhadap Human Development Index (HDI). Sedangkan jumlah penduduk miskin dan PDRB perkapita berpengaruh signifikan terhadap HDI pada 6 daerah tertinggal di pulau Jawa. Maka cara yang efektif untuk percepatan peningkatan pertumbuhan ekonomi pada daerah tertinggal yang berkaitan dengan HDI melalui penurunan jumlah penduduk miskin dengan penciptaan lapangan kerja yang bersifat labour intensive yang pada gilirannya akan meningkatkan PDRB perkapita. Sehingga, peningkatan PDRB perkapita akan meningkatkan Human Development Index (HDI) dimana HDI
\end{abstract}


merupakan salah satu indikator dalam pertumbuhan ekonomi suatu daerah.

Keywords: Daerah Tertinggal, Human Development Index, PDRB perkapita, kemiskinan, angkatan kerja

\section{PENDAHULUAN}

Pulau Jawa merupakan wilayah yang mempunyai peran paling tinggi dalam pembentukan PDB Nasional. Pada gambar 1 terlihat bahwa Pulau Jawa memberikan kontribusi tertinggi yaitu sebesar $58.4 \%$. Selanjutnya diikuti oleh Sumatra (22.02\%), Kalimantan (7.72\%), Bali dan Nusa Tenggara (3.18\%) serta yang terakhir Maluku dan Papua (2.53\%). Berdasarkan Peraturan Republik Indonesia nomor 131 tahun 2015 tentang penetapan daerah tertingal tahun 2015-2019, pulau Jawa sebagai kontribusi pertumbuhan ekonomi tertinggi di Indonesia nyatanya menyumbang 6 dari 122 daerah tertinggal di Indonesia (RI, 2015).

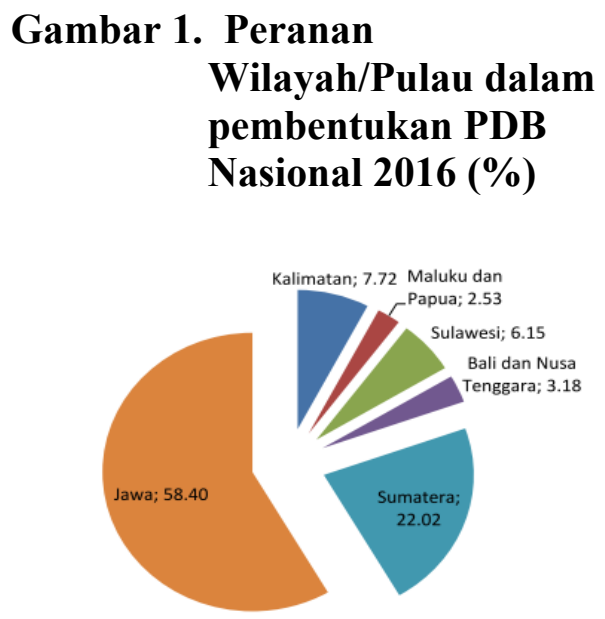

Sumber : BPS, 2016

Daerah tertinggal sendiri merupakan kabupaten yang wilayah serta masyarakatnya kurang berkembang jika dibandingkan dengan wilayah lain dalam skala nasional. Suatu daerah sendiri ditetapkan sebagai daerah tertinggal berdasarkan kriteria :

perekonomian masyarakat sumberdaya manusia sarana dan prasarana kemampuan keuangan daerah aksesibilitas

karakteristik daerah

Terdapat 6 kabupaten di pulau Jawa yang termasuk pada kategori daerah tertinggal yaitu Kab. Bondowoso, Kab. Situbondo, 
Kab. Bangkalan, Kab.Sampang,

Kab. Pandeglang, Kab. Lebak.

Seperti yang telah disampaikan bahwa salah satu kriteria daerah tertinggal yaitu mengenai sumberdaya manusia, hal ini bisa diukur melalui HDI (Human Development Index). Pada grafik 1 menggambarkan perbandingan
HDI dari daerah tertinggal dengan rata- rata HDI nasional tahun 2016. Rata-rata HDI nasional yaitu sebesar $69.55 \%$ sedangkan masingmasing HDI dari daerah yang termasuk dalam kategori daerah tertinggal memiliki HDI yang jauh dibawah rata-rata HDI nasional.

Gambar 2. Perbandingan HDI daerah tertinggal dan nasional 2016 (\%)

Sumber : BPS, 2016

Selain itu HDI (Human Development Index) juga merupakan indikator yang penting dalam hal penyebab kemunduran wilayah. Menurut penelitian Anand \& Ravallion (2013) yang berjudul Human Development in Poor Countries menyatakan bahwa peningkatan dari HDI akan mengurangi ketimpangan pendapatan dan peningkatan sarana publik pada negara miskin dengan studi kasus negara Sri Lanka. Pada umumnya hal ini berkorelasi positif pada suatu wilayah/negara, yaitu angka harapan hidup dan kemakmuran merupakan salah satu yang dapat mempengaruhi tingkat 
kemiskinan wilayah. Berdasarkan penelitian dari Martínez (2012) bahwa HDI berpengaruh positif terhadap ketimpangan wilayah, sehingga muncul gap daerah maju dan tertinggal.

Nurkse (1953) dalam bukunya Problem of Capital Formation on Underdeveloped Countries menyatakan adanya hubungan yang saling terikat dalam teori lingkaran kemiskinan. Dimana suatu negara akan tetap miskin dan akan mengalami banyak kesulitan untuk mencapai pembangunan ekonomi yang lebih baik. Rendahnya kualitas SDM suatu wilayah akan menyebabkan peningkatan jumlah penduduk miskin, yaitu jika SDM rendah mencerminkan rendahnya produktivitas maka investasi juga akan menurun yang menyebabkan terbatasnya lapangan kerja sehingga jumlah pengangguran meningkat dan berimplikasi pada peningkatan jumlah penduduk miskin pada daerah tersebut. Jumlah penduduk miskin pulau jawa merupakan yang tertinggi di Indonesia yaitu sekitar 14,8 juta jiwa atau sebanyak 53\%. Disisi lain pulau Jawa merupakan kontribusi pertumbuhan ekonomi tertinggi di Indonesia.

\section{Gambar 3. Jumlah Penduduk Miskin menurut Pulau 2016 (ribu jiwa)}

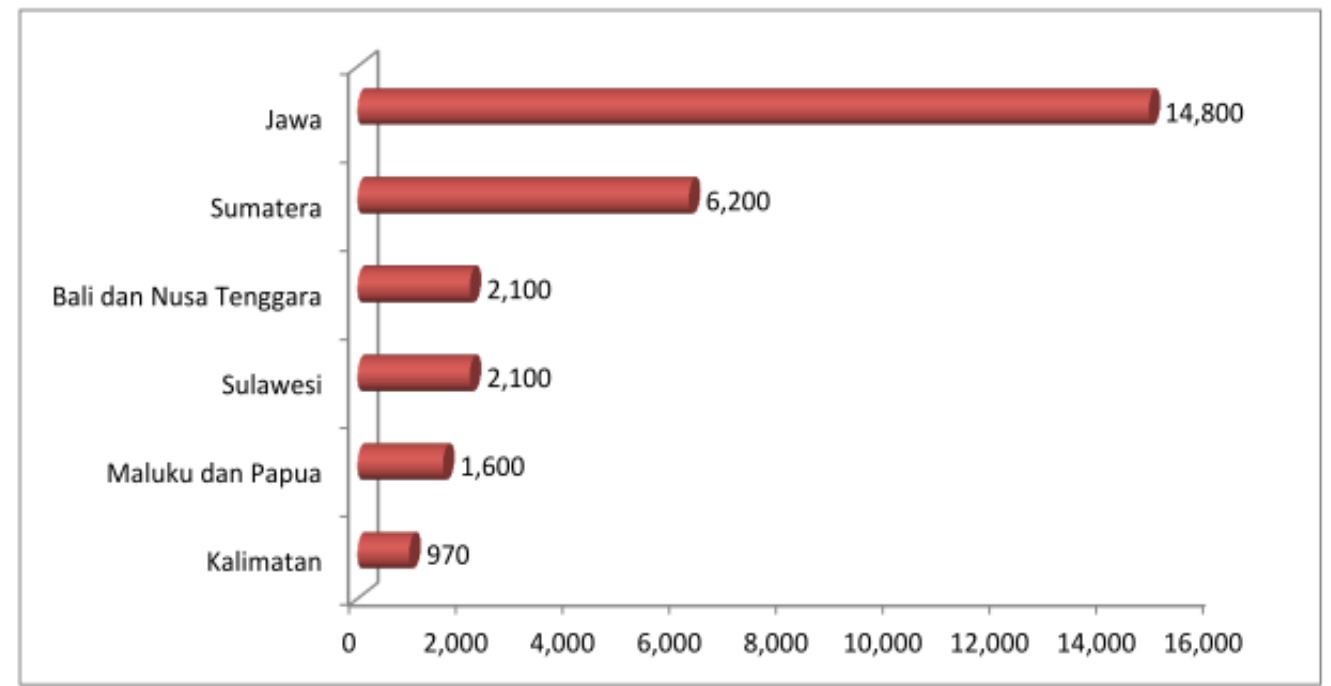

Sumber : BPS, 2016

Selanjutnya, 
dapat menggambarkan pula tingkat kesejahteraan suatu daerah. Jika angkatan kerja suatu daerah tinggi maka akan mempengaruhi HDI dimana kesejahteraan masyarakat cenderung tinggi. Daya beli masyarakat yang merupakan salah satu indikator HDI juga akan meningkat. Angkatan kerja berpengaruh signifikan sebesar 5.58 dan berhubungan positif terhadap HDI. Dengan kata lain, jika terjadi peningkatan angkatan kerja maka HDI pada daerah tersebut juga meningkat (Hariwan, 2012).

Salah satu yang juga dapat menggambarkan tingkat kesejahteraan penduduk suatu wilayah selanjutnya adalah angka PDRB perkapita. Jika semakin tinggi angka PDRB perkapita suatu daerah maka semakin tinggi pula potensi sumber penerimaan daerah tersebut, dikarenakan tingginya pendapatan masyarakat pada daerah tersebut. Studi pada Shah (2016) menunjukkan bahwa human development index secara signifikan dipengaruhi oleh GDP perkapita, Literacy rate, life expectancy at birth, Index Gini, fertility rate dan Co2 emission. Sesuai dengan teori yang ada jika GDP perkapita meningkat maka HDI akan mengalami peningkatan. Pada kasus daerah tertinggal, 6 daerah tersebut memiliki PDRB perkapita yang jauh lebih kecil diantara rata-rata PDRB perkapita pulau Jawa. Terlihat pada grafik 3 dari tahun 2010-2015, PDRB perkapita selalu meningkat pada setiap kabupaten kecuali pada Sampang dan Bangkalan yang nilainya cukup fluktuatif.

\section{Gambar 4. PDRB perkapita 6 Daerah Tertinggal 2010-2016 (ribu rupiah)}




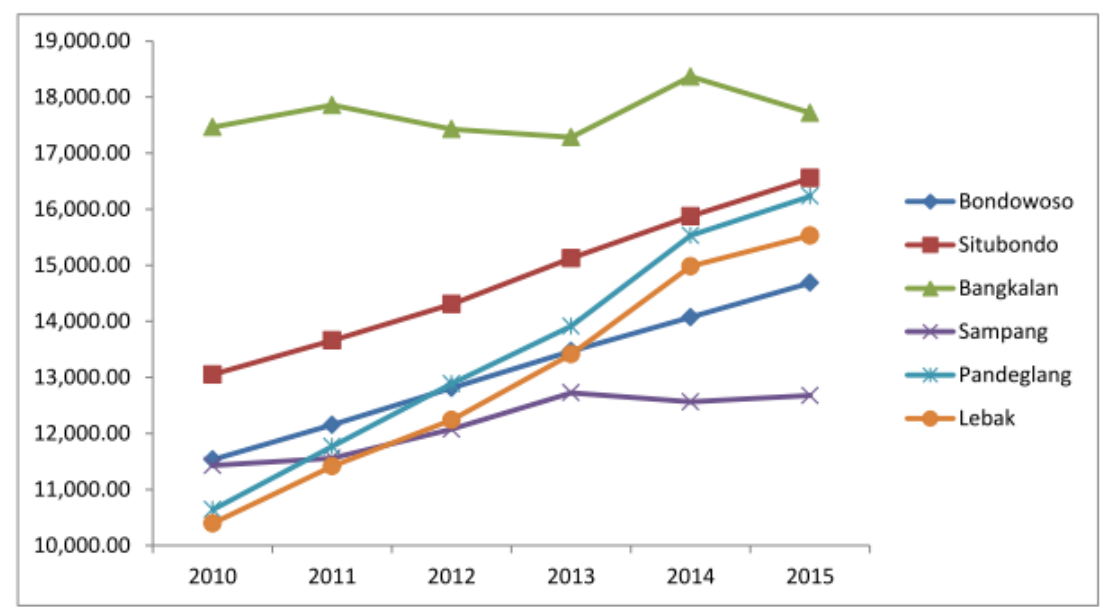

Sumber : BPS, 2016

Berdasarkan latar

belakang permasalahan tersebut diatas, maka penulis merasa perlu diadakan penelitian mengenai permasalahan "Analisis faktor yang mempengaruhi Human Development Index (HDI) pada 6 daerah tertinggal di Pulau Jawa tahun 2010-2016"

Tujuan dari penelitian ini adalah menganalisis pengaruh Jumlah penduduk miskin, angkatan kerja, serta PDRB perkapita terhadap Human Development Index (HDI) pada 6 daerah tertinggal di Pulau Jawa Tahun $2010-2015$.

\section{METODE PENELITIAN}

Penelitian ini akan mengamati pengaruh Jumlah penduduk miskin, PDRB perkapita, serta angkatan kerja terhadap Human Development Index (HDI) pada 6 daerah tertinggal di Pulau Jawa yaitu Kab. Bondowoso, Kab. Situbondo, Kab. Bangkalan, Kab.Sampang, Kab. Pandeglang, Kab. Lebak. Maka untuk menjawab permasalahan serta tujuan tersebut peneliti memilih menggunakan metode kuantitatif dengan periode pengamatan tahun 2010 - 2015. Metode analisis yang digunakan yaitu analisis regresi data panel dengan dua metode Fixed Effect Method (FEM) dan Random Effect Method (REM) (Gujarati, 2002). Namun sebelum dilakukan pengestimasian model dalam penelitian ini, dilakukan uji spesifikasi untuk menganalisis antara penggunaan FEM atau REM yaitu menggunakan Uji Hausman 
(Hausman-test). Berikut model

ekonometrika dari penelitian ini :

$$
H D I=\beta_{0}+\beta_{1} \text { Proverty }+1
$$

Keterangan :

HDI = Human Development Index

Poverty $=$ Jumlah penduduk miskin

$$
\begin{array}{ll}
\mathrm{AK} & =\text { Angkatan Kerja } \\
\mathrm{PDRB}= & \text { PDRB perkapita } \\
\beta_{0} \quad= & \text { Konstanta } \\
\beta_{123}= & \text { Koefisien Regresi (variabel } \\
& \text { yang diestimasi) } \\
\varepsilon & =\text { Error term (variabel } \\
& \text { gangguan) }
\end{array}
$$

HASIL DAN PEMBAHASAN

Gambaran Umum HDI pada daerah tertinggal di Pulau Jawa

Pembangunan ekonomi yang bersifat sustainable jelas sangat pro terhadap peningkatan kualitas sumberdaya manusia. HDI sendiri pada dasarnya dapat menggambarkan sekaligus tiga komponen yaitu umur panjang dan sehat, pengetahuan (pendidikan), serta standar hidup layak. Jika pemerintah fokus dalam hal peningkatan kualitas SDM melalui HDI maka diharapkan akan mengurangi tingkat kemiskinan yang ada melalui peningkatan angkatan kerja, peningkatkan pembangunan ekonomi sehingga tidak terjadi gap antara daerah yang maju dengan daerah tertinggal.

Gambar 5. Tren HDI 6 daerah tertinggal di Pulau Jawa 2010-2016 (\%)

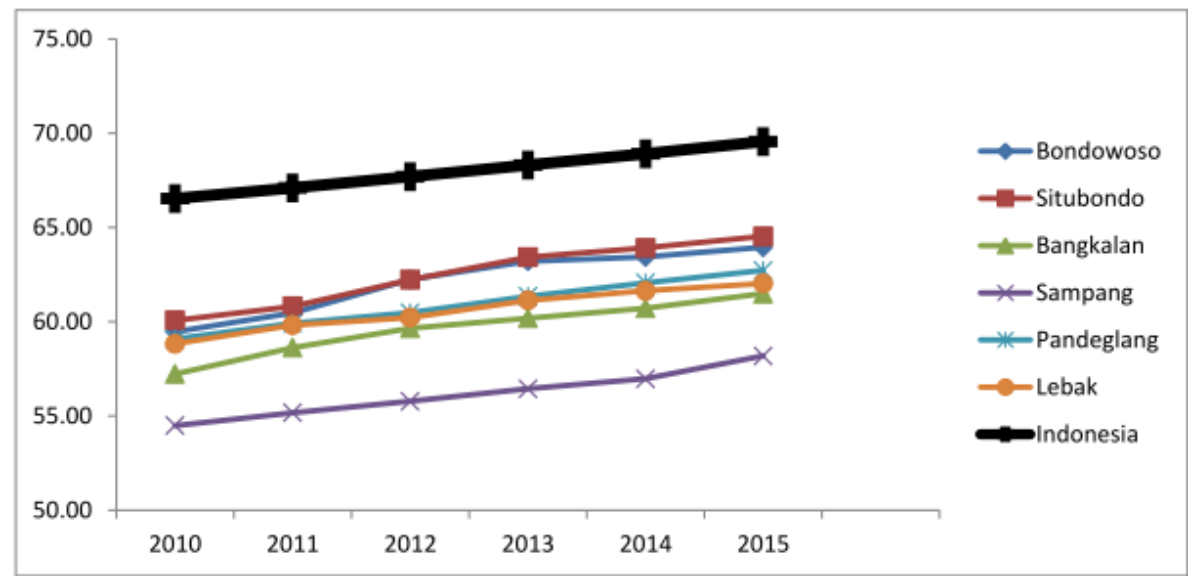

Sumber : BPS, 2016

Pulau Jawa menyumbang

6 dari 122 daerah tertinggal di Indonesia. Dan nyatanya 6 daerah tersebut memiliki HDI yang jauh lebih rendah dibandingkan HDI rata-rata nasional. Pada Kab. Bondowoso, Kab. Situbondo, Kab. Bangkalan, Kab.Sampang, Kab. 
Pandeglang, Kab. Lebak nilai

HDI dari tahun 2010-2015 mengalami kenaikan tetapi tidak secara signifikan. Pada grafik 4 terlihat bahwa rata-rata HDI Indonesia jauh berada diatas dari 6 daerah tertinggal di Pulau Jawa. Hal ini sesuai dengan peraturan pemerintah dalam undang- undang bahwa salah satu indikator daerah tertinggal adalah rendahnya SDM pada wilayah tersebut.
Hasil uji regresi data panel ini menggunakan Random Effect Model (REM). Dengan variabel dependen yaitu HDI (Y), dan variabel independennya yaitu Jumlah penduduk miskin (X1), Angkatan kerja (X2), dan PDRB per kapita (X3). Berikut model regresi berdasarkan hasil analisis data diatas :

$$
\begin{aligned}
& Y=2.785916-0,112197 \\
& X 1+0.030811 \times 2+ \\
& 0,154088 \times 3+\varepsilon
\end{aligned}
$$

Hasil Analisis Data

DependearialoI

MethbanteG (Srosetiomm defiects)

Date1/0817niles: 19

Sampredo 15

Periónlolucted:

Crosesetionsluched:

Totpath ndala mobdervabions:

Swa myd rostim autón mponzemitan ces

Variable CoefficisterrortStatisticProb.

POVERTYO. 11219701532032372 B.OOOO AK $0.030801030197 .02035 D .3152$ PDRB O.1540\&81773868957@.0000 C 2.785906451010 .176930 .0000

Effestrecification

S.D. Rho

Crossetiandom 0.015170 .6647

Idiosyneratic

\begin{tabular}{|c|c|c|}
\hline \multicolumn{3}{|c|}{ Weighttadistics } \\
\hline Rsquared & O.820384teahapendant & 1.141721 \\
\hline $\begin{array}{l}\text { Adjusted } \\
\text { squared }\end{array}$ & 0.803545. rependent & 0.02543 \\
\hline \multicolumn{3}{|c|}{ S.Fofregressiono.0 1127 sturquaredid } \\
\hline Fstatistic & 48.719410urbukatssoant & 1.9744 \\
\hline
\end{tabular}
0.010778 .3353 random 


\begin{tabular}{lcll}
\hline Prob(F-statistic) & 0.000000 & \\
\hline \multicolumn{4}{c}{ Unweighted Statistics } \\
\hline R-squared & 0.853855 & Mean dependent var & $\mathbf{4 . 0 9 9 4 4 4}$ \\
\hline Sum squared resid & $\mathbf{0 . 0 0 9 6 4 4}$ & Durbin-Watson stat & $\mathbf{0 . 4 5 3 1 3 4}$ \\
\hline
\end{tabular}

Sumber: Data diolah

Koefisien regresi variabel jumlah penduduk miskin (X1) yang bernilai $-0,112197$ menjelaskan bahwa apabila terjadi peningkatan pada variabel jumlah penduduk miskin sebesar 1 satuan maka akan terjadi penurunan pada variabel HDI (Y) sebesar 0,112197. Selanjutnya pada koefisien regresi variabel angkatan kerja (X2) yang bernilai 0.030811 menjelaskan bahwa jika terjadi kenaikan variabel angkatan kerja sebesar 1 satuan maka akan meningkatkan pula variabel HDI (Y) sebesar 0.030811 . Serta pada variabel ketiga yaitu PDRB perkapita (X3) koefisien regresinya bernilai 0,154088. Menjelaskan bahwa terjadinya peningkatan variabel PDRB perkapita sebesar 1 satuan maka akan meningkatkan variabel HDI (Y) sebesar 0,154088.

Berdasarkan output hasil regresi dapat diketahui Koefisien determinasi $\left(\mathrm{R}^{2}\right)$ sebesar 0,8204 atau sebesar 82,04\%. Ini berarti bahwa kontribusi dari variabel $\mathrm{X} 1$, $\mathrm{X} 2$ dan X3 dapat menjelaskan pengaruhnya terhadap variabel HDI (Y) sebesar $82,04 \%$. Sedangkan sisanya yaitu sebesar $17,96 \%$ dijelaskan oleh variabel lain diluar persamaan regresi pada penelitian kali ini.Uji $\mathrm{F}$ statistik digunakan untuk menguji hipotesis pengaruh simultan dari variabel $\mathrm{X}$ terhadap variabel Y. Berdasarkan hasil didapatkan Sig F $(0,000)$ yang lebih kecil dari $5 \% \quad(0,05)$ menunjukkan bahwa $\mathrm{H} 1$ diterima dan $\mathrm{HO}$ ditolak yang berarti bahwa variabel X1，X2， dan X3 secara bersama sama mempunyai pengaruh yang signifikan terhadap variabel HDI (Y).

Selanjutnya dilakukan uji $\mathrm{t}$ statistik untuk mengetahui pengaruh parsial dari masingmasing variabel $\mathrm{X}$ terhadap variabel Y. Berikut hasil dari uji parsial masing-masing variabel independen terhadap variabel 
dependen :

Variabel jumlah penduduk miskin (X1) dengan nilai signifikansi 0,000 (lebih kecil dari alpha $5 \%$ atau 0,05$)$ yang berarti bahwa variabel jumlah penduduk miskin (X1) berpengaruh signifikan terhadap HDI (Y).

Variabel angkatan kerja (X2) dengan nilai signifikansi 0,3152 (lebih besar dari alpha $5 \%$ atau 0,05 ) yang berarti bahwa variabel angkatan kerja (X2) tidak berpengaruh signifikan terhadap HDI (Y).
Variabel PDRB perkapita (X3) dengan nilai signifikansi 0,000 (lebih kecil dari alpha 5\% atau 0,05) yang berarti bahwa variabel PDRB perkapita (X3) berpengaruh signifikan terhadap variabel HDI (Y).

\section{Pembahasan Hasil Analisis}

Dalam penelitian kali ini terdapat variabel dependen yaitu HDI (Y) dengan variabel independen yaitu variabel Jumlah penduduk miskin (X1), Angkatan kerja (X2), dan PDRB per kapita (X3).

Tabel 1. Pengaruh dan hubungan antar variabel

\begin{tabular}{clcc}
\hline & \multicolumn{1}{c}{ Variabel } & $\begin{array}{c}\text { Hasil } \\
\text { Output }\end{array}$ & Keterangan \\
\hline $\begin{array}{c}\text { Variabel } \\
\text { Dependen }\end{array}$ & HDI (Y) & & \\
\hline Variabel & Jumlah Penduduk Miskin (X1) & Negatif & Signifikan \\
\hline Independen & Angkatan Kerja (X2) & Positif & $\begin{array}{c}\text { Tidak } \\
\text { Signifikan }\end{array}$ \\
\hline & PDRB perkapita (X3) & Positif & Signifikan
\end{tabular}

Sumber : penulis, 2016

\section{Setelah dilakukan regresi} data panel melalui model random effect diperoleh hasil bahwa variabel jumlah penduduk miskin berhubungan negatif dan berpengaruh secara signifikan terhadap HDI. Dengan kata lain, penurunan jumlah penduduk miskin yang terjadi pada 6 daerah tertinggal di Pulau Jawa yaitu Kab. Bondowoso, Kab. Situbondo, Kab. Bangkalan, Kab.Sampang, Kab. Pandeglang, Kab. Lebak ternyata 
efektif terhadap peningkatan nilai

HDI pada 6 daerah tertinggal

tersebut, begitupula sebaliknya.

Grafik 6. Nilai HDI dan Jumlah Penduduk Miskin Kabupaten Bangkalan tahun 2010-2016 (ribu jiwa)

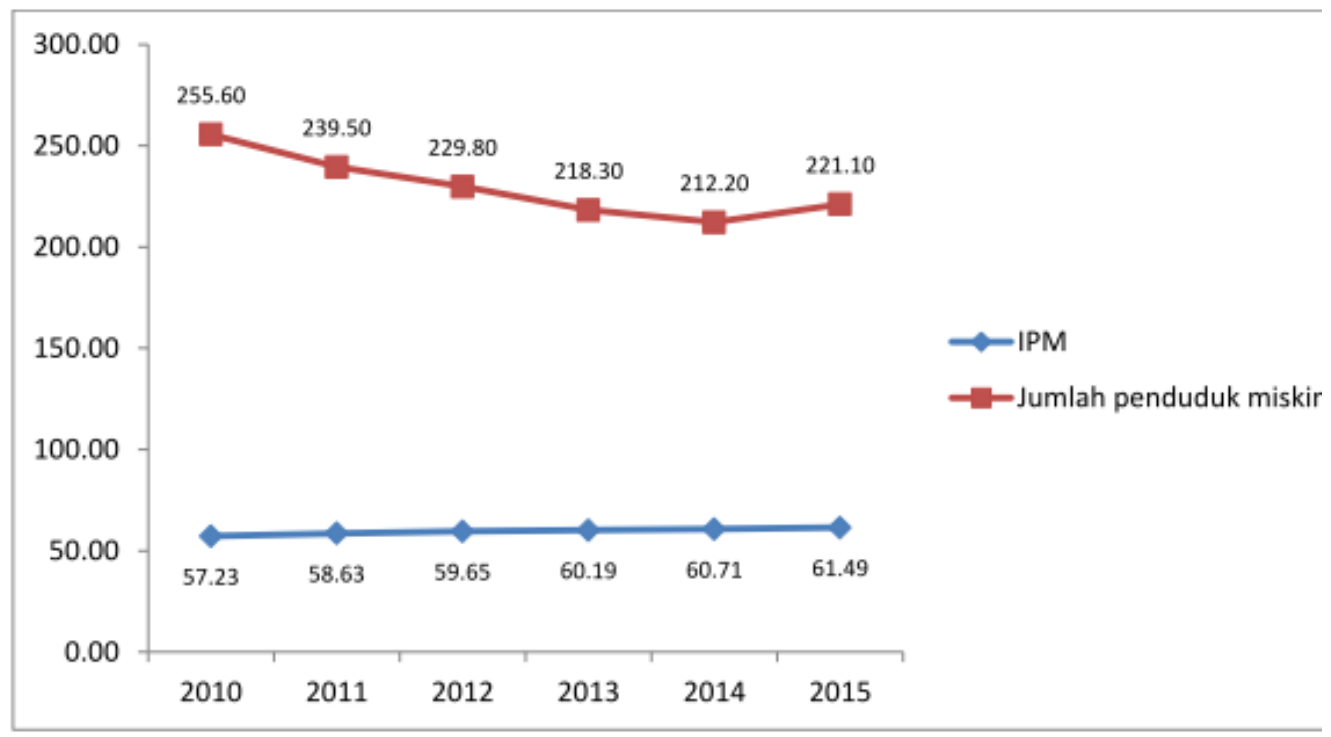

Sumber : BPS, 2016

Grafik

diatas

menggambarkan perbandingan

fluktuasi antara HDI dan Jumlah penduduk miskin pada Kab. Bangkalan pada tahun 2010-2016. Kabupaten Bangkalan disini merupakan wilayah yang termasuk daerah tertinggal dengan jumlah penduduk miskin tertinggi. Pada grafik terlihat tren dari jumlah penduduk miskin, pada tahun 2010-2011 terjadi penurunan pada penduduk miskin $(239.50$ ribu jiwa) sehingga meningkatkan HDI (58.63\%). Jumlah penduduk miskin di Kab. Bangkalan ini dari tahun ke 
tahunnya cenderung menurun, namun pada tahun 2014-2015 jumlah penduduk miskin mengalami peningkatan sebesar 221,10 ribu jiwa, namun HDI tetap mengalami peningkatan walaupun hanya sedikit presentasenya.

Nilai HDI Kab. Bangkalan berada jauh di bawah rata-rata nasional, hal ini yang mengakibatkan Kab. Bangkalan masih menjadi daerah tertinggal. Kab. Bangkalan merupakan salah satu wilayah yang termasuk dalam kawasan Industri

\section{GERBANGKERTASUSILA,} namun dengan masuknya Kab. Bangkalan pada kawasan industri tersebut nampaknya tidak mempengaruhi secara signifikan pembangunan ekonomi pada wilayah tersebut. Kab. Bangkalan masuk ke dalam kategori daerah tertinggal dengan pertumbuhan ekonomi rendah dan HDI rendah. Aksesibilitas Kab. Bangkalan yang tinggi dengan Surabaya, Lamongan, Sidoarjo juga tidak berpengaruh signifikan terhadap pembangunan wilayahnya. Kondisi wilayah sekitar kota yang semakin memburuk menggambarkan konsep dari teori Kausasi Kumulatif (Myrdal, 1957), kekuatan pasar disini cenderung memperburuk kesenjangan antara daerah maju dan daerah tertinggal.

Selanjutnya menurut Hariwan (2012) dengan judul analisis HDI pada 5 wilayah hasil pemekaran di Jawa Barat bahwa peningkatan pendapatan penduduk rata-rata dan jumlah tenaga kerja signifikan meningkatkan HDI. Namun pada penelitian kali ini ternyata variabel angkatan kerja tidak berpengaruh signifikan (hanya sekitar 0.030811 ) terhadap perubahan HDI pada 6 daerah tertinggal yang berada di Pulau Jawa tersebut.

Salah satu indikator dalam HDI adalah indeks standar hidup layak. Jika banyaknya tenaga kerja yang terserap meningkat maka daya beli masyarakatpun akan meningkat, sehingga standar kehidupan layak masyarakat juga mengalami peningkatan. Namun pada penelitian kali ini angkatan kerja tidak mempengaruhi perubahan HDI pada 6 daerah 
tertinggal, karena berdasarkan Simanjuntak (2001) mengatakan bahwa angkatan kerja terdiri dari orang yang bekerja dan penganggur. Dimasukkannya angka penganggur menyebabkan angka beban ketergantungannya tinggi. Seharusnya variabel yang lebih tepat untuk mengganti adalah jumlah tenaga kerja yang terserap pada masing-masing daerah tertinggal.

Variabel terakhir yaitu PDRB perkapita menunjukkan koefisien positif sebesar 0,154088 dan berpengaruh signifikan terhadap perubahan HDI pada 6 daerah tertinggal. Grafik menggambarkan perbandingan PDRB per kapita antara 6 daerah tertinggal di Pulau Jawa dengan rata-rata PDRB perkapita Indonesia tahun 2016. PDRB per kapita 6 daerah tertinggal nyatanya memang berada jauh dibawah garis rata-rata Indonesia. PDRB perkapita terendah terletak pada Kab. Sampang, hal ini menunjukkan bahwa Kab. Sampang merupakan daerah tertinggal yang mempunyai kondisi ekonomi paling buruk di Pulau Jawa. Disini PDRB per kapita atau pendapatan penduduk rata-rata merupakan suatu alat ukut untuk memperbaiki kapabilitas manusia sehingga terjadi peningkatan pada daerah. Dengan kata lain, supaya daerah tersebut bisa lebih baik dari keadaaan sebelumnya.

\section{Grafik 7. Perbandingan PDRB per kapita 6 daerah tertinggal di Pulau Jawa dan rata-rata nasioanl tahun 2016 (ribu rupiah)}




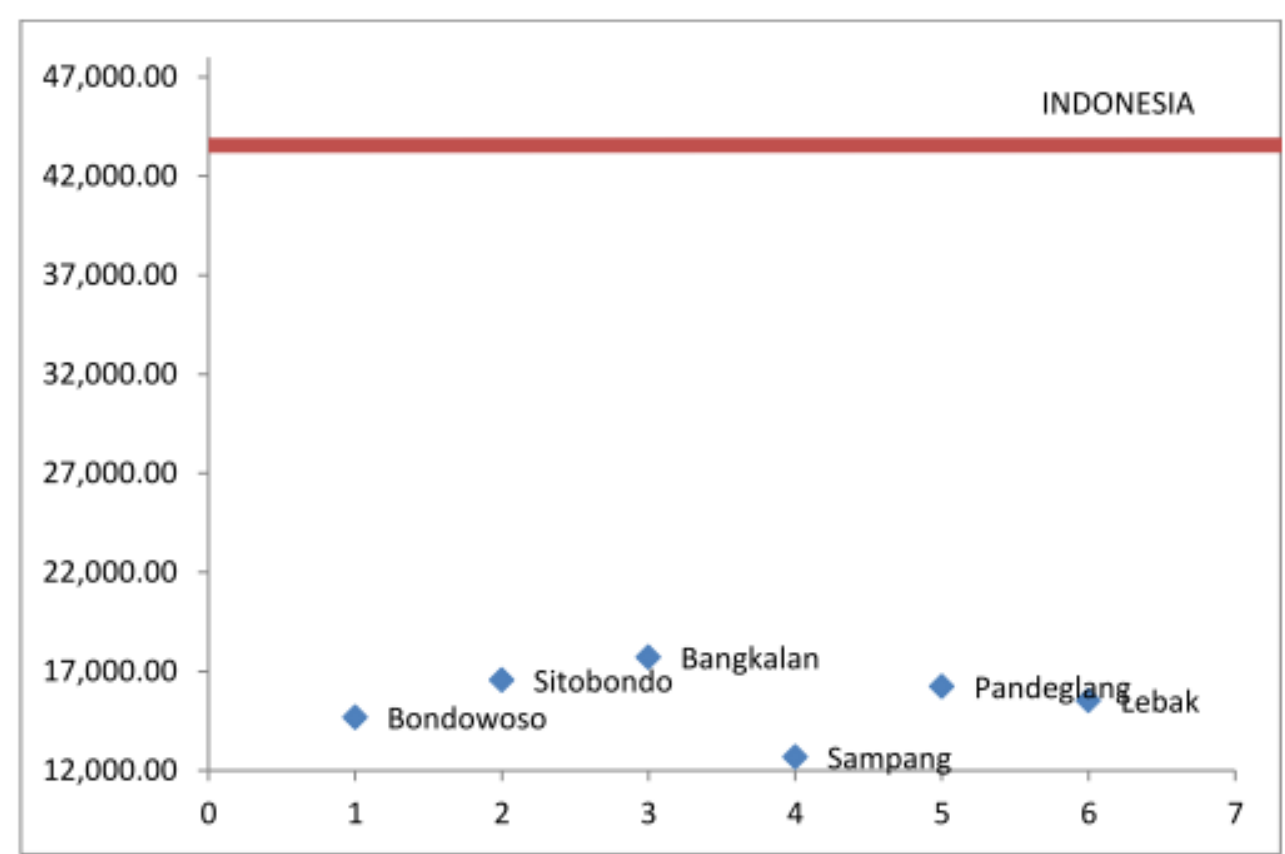

Sumber : BPS, 2016

Peningkatan PDRB per kapita pada setiap tahunnya dapat menggambarkan kemampuan individu dalam rangka meningkatkan standar hidup dan kualitas kesehatan maupun pendidikannya, sehingga bisa dikatakan bahwa indikator HDI lebih representatif dalam menggambarkan tingkat kesejahteraan masyarakat atau tingkat kesejahteraan suatu daerah. Dalam kasus daerah tertinggal, peningkatan PDRB per kapita diperlukan untuk peningkatan kesejahteraan masyarakat melalui peningkatan standar hidup sehingga pada akhirnya akan meningkatkan HDI. Karena PDRB perkapita yang tinggi pada daerah tertinggal akan membentuk kualitas manusia yang tinggi pula.

\section{KESIMPULAN}

Penelitian ini bertujuan untuk menganalisis pengaruh Jumlah penduduk miskin, angkatan kerja, serta PDRB perkapita terhadap Human Development Index (HDI) pada 6 daerah tertinggal di Pulau Jawa Tahun 2010 - 2015. Maka berdasarkan hasil analisis menggunakan regresi data panel melalui model Random Effect sebagai berikut :

Hasil analisis menunjukkan bahwa Jumlah penduduk miskin, angkatan kerja, serta PDRB perkapita secara bersama-sama 
berpengaruh signifikan

terhadap Human Development Index (HDI) pada 6 daerah tertinggal di Pulau Jawa.

Namun melalui uji parsial menunjukkan bahwa variabel angkatan kerja tidak berpengaruh signifikan terhadap Human Development Index (HDI). Sedangkan jumlah penduduk miskin dan PDRB perkapita berpengaruh signifikan terhadap Human Development Index (HDI) pada 6 daerah tertinggal di pulau Jawa. Pada dasarnya peningkatan sumberdaya melalui indikator HDI diharapkan mampu mengentas kemiskinan sehingga terjadi kesejahteraan yang lebih baik dimasa yang akan datang pada daerah tertinggal yaitu Kab. Bondowoso, Kab. Situbondo, Kab. Bangkalan,

Kab.Sampang, Kab.

Pandeglang, Kab. Lebak.

Berdasarkan penelitian kali ini cara yang efektif untuk percepatan peningkatan pertumbuhan ekonomi pada daerah tertinggal yang berkaitan dengan Human

Development Index (HDI)

melalui penurunan jumlah penduduk miskin dengan penciptaan lapangan kerja yang bersifat labour intensive yang pada gilirannya akan meningkatkan PDRB perkapita. Sehingga, peningkatan PDRB perkapita akan meningkatkan Human Development Index (HDI) dimana HDI merupakan salah satu indikator dalam pertumbuhan ekonomi suatu daerah.

\section{DAFTAR PUSTAKA}

Anand, S., \& Ravallion, M. (2013).

Human

Development in Poor Countries: On the Role of Private Incomes and Public Services. The Journal of Economic Perspectives, 7(1), 133-150. Retrieved from http://www.jstor.org/stable/ 2138325

Gujarati, D. N. (2002). Dasar Dasar Ekonometrika (5th ed.). Jakarta: Salemba Empat. 
Hariwan, P. (2012). Analisis Indeks Pembangunan Manusia Pada 5 Wilayah Hasil Pemekaran di Jawa Barat Analysis Of Human Development Index In Five Cities, (2005).

Martínez, R. (2012). Inequality and the new human development index. Applied Economics Letters, 19(6), 533-535.

https://doi.org/10.1080/135 $\underline{04851.2011 .587762}$

Myrdal, G. (1957). Economic Theory and

Underdeveloped Regions. London: Duckworth.

Nurkse, R. (1953). Problems of Capital Formation in Underdeveloped

Countries. New York: Oxford University Press.

RI, P. (2015). Peraturan Presiden Nomor 131 Tahun 2015
Tentang Penetapan

Daerah Tertinggal Tahun 2015-2019. Peraturan

Presiden Nomor 131

Tahun 2015 Tentang

Penetapan Daerah

Tertinggal Tahun 20152019 ,

1.

https://doi.org/10.1017/C

BO9781107415324.004

Shah, S. (2016). Mp r a. Determinants of Human Development Index: $A$ Cross-Country Empirical Analysis.

https://doi.org/10.1227/0

1.NEU.0000349921.1451

$9.2 \mathrm{~A}$

Simanjuntak, P. J. (2001). Pengantar Ekonomi Sumber Daya Manusia. Jakarta: Fakultas Ekonomi Universitas Brawijaya. 